\title{
Chicken leptin receptor is functional in activating JAK-STAT pathway in vitro
}

\author{
Hiromi Adachi, Yasumasa Takemoto, Takashi Bungo ${ }^{\mathbf{1}}$ and Takeshi Ohkubo \\ Faculty of Agriculture, Kagawa University, 2393 Ikenobe, Miki, 761-0795 Kagawa, Japan \\ ${ }^{1}$ Laboratory of Animal Behavior and Physiology, Department of Bioresource Science and Technology, Graduate School of Biosphere Science, \\ Hiroshima University, 1-4-4, Kagamiyama, Higashi-Hiroshima, 739-8528 Hiroshima, Japan \\ (Correspondence should be addressed to T Ohkubo; Email: ohkubo@ag.kagawa-u.ac.jp)
}

\begin{abstract}
Leptin is a cytokine-like hormone that regulates food intake and energy homeostasis via its interaction with the leptin receptor (LEPR) located in the target tissues. Leptindependent signal transduction pathways have been well characterised in mammals but less is known about them in other vertebrates. In birds, although the existence of the LEPR has been confirmed, the identity of the natural ligand for the LEPR is controversial and the signalling cascade is not fully understood either. Here, we describe the in vitro expression of chicken LEPR (chLEPR), which can mediate the leptin signal. Murine leptin specifically bound with the chLEPR, which initiated the activation of luciferase in chLEPR-expressing cells. Leptin stimulation led to phosphorylation of signal transducers and activators of

transcription 3 (STAT3) via chLEPR, and Janus kinase ${ }^{-2}$ $\left(\mathrm{JAK}^{-2}\right)$ inhibitor partially blocked leptin-induced luciferase activation in CHO-K1 cells stably expressing chLEPR (CHO-chLEPR). RNA interference for chLEPR reduced the induction rate of luciferase activity by leptin in $\mathrm{CHO}-$ chLEPR cells. Furthermore, we found that leptin phosphorylated STAT3 and increased luciferase activity in LMH cells, a chicken hepatoma cell line, transiently expressing chLEPR. These results strongly suggest that the chLEPR is functional in activating the JAK-STAT pathway, which may indicate that the LEPR expressed in chicken tissues is capable of binding endogenous ligand as well as exogenous mammalian leptin, leading to physiological actions.

Journal of Endocrinology (2008) 197, 335-342
\end{abstract}

\section{Introduction}

Leptin is an adipocyte-derived hormone that regulates feeding behaviour and energy homeostasis in mammals (Campfield et al. 1995, Halaas et al. 1995, Pelleymounter et al. 1995). The leptin signal is mediated through a specific receptor located in the target tissues and the leptin receptor (LEPR) belongs to the class I cytokine receptor superfamily that shares common structural features and signal transduction pathways (Tartaglia et al. 1995). The LEPR is known to exist as multiple isoforms that are derived from one gene using alternative splicing in mammals (Lee et al. 1996). The longest isoform, LEPRb, is able to transduce a signal using the Janus kinase (JAK)-signal transducers and activators of transcription (STAT) signal transduction pathway. Following leptin binding, LEPR-associated JAK rapidly phosphorylates STAT1 and STAT3 (Baumann et al. 1996, Ghilardi et al. 1996, Rosenblum et al. 1996). The phosphorylated STATs form homo- or heterodimers and these migrate to the nucleus to initiate gene transcription from STAT-responsive elements (Schindler \& Darnell 1995).

In birds, although cDNA-encoding chicken leptin has been cloned and sequenced (Taouis et al. 1998, Ashwell et al. 1999), other researchers have not been able to confirm the existence of the gene (Friedman-Einat et al. 1999, Pitel et al. 2000, Dunn et al. 2001, Amills et al. 2003). Therefore, the existence of an avian leptin homologue is controversial. However, cDNAs corresponding to the mammalian LEPRb were reported in domestic birds (Horev et al. 2000, Ohkubo et al. 2000, Richards \& Poch 2003) and radioactivity was detected in multiple tissues after infusing radiolabelled leptin in chickens (McMurtry et al. 2004). In addition, we recently demonstrated that chicken LEPR (chLEPR) protein occurred in chicken brain and LMH cells, a chicken hepatoma cell line (Ohkubo et al. 2007). These findings may indicate that chLEPR occurring in chicken tissues is able to bind leptin, resulting in physiological processes that include food intake (Denbow et al. 2000), immune responses (Lohmus et al. 2004) and ovarian function (Paczoska-Eliasiewicz et al. 2003). Nevertheless, signal transduction through the avian LEPR has not been established either in vivo or in vitro.

In mammals, a functional assay for measuring leptin, which in conjunction with STAT activation leads to the induction of firefly luciferase, has been demonstrated (Rosenblum et al. 1998, Ju et al. 2001, Friedman-Einat et al. 2003); this should be useful in determining biologically active leptin. In the present study, to investigate whether chLEPR is able 
to mediate the leptin signal, we established a cell line stably expressing chLEPR, with which it was possible to measure leptin-induced luciferase activity, as in a similar system established in mammals.

\section{Materials and Methods}

\section{Plasmids}

An expression vector containing the chLEPR cDNA (pCIchLEPR) was described previously (Ohkubo et al. 2007). The construct pAH32, an expression vector transactivated by leptin (Rosenblum et al. 1996, 1998), was a kind gift from Dr C I Rosenblum (Merck Research Laboratories). pRL-Tk, a vector expressing Renilla reniformis luciferase under the control of thymidine kinase, was obtained from Promega.

\section{Cell culture}

CHO-K1 cells, a Chinese hamster ovary cell line, were maintained in nutrient mixture Ham's F-12 medium (SigmaAldrich Japan) containing 10\% fetal bovine serum (FBS), 100 units $/ \mathrm{ml}$ penicillin and $100 \mu \mathrm{g} / \mathrm{ml}$ streptomycin at $37^{\circ} \mathrm{C}$ in an atmosphere of $95 \%$ air and $5 \% \mathrm{CO}_{2}$. COS-7 cells, a monkey kidney cell line, were maintained in Dulbecco's modified Eagle's medium (DMEM; Sigma-Aldrich Japan) supplemented with $10 \%$ FBS or $10 \%$ LiforCell FBS replacement (Lifeblood Medical Inc., Freehold, NJ, USA) in an atmosphere of $5 \% \mathrm{CO}_{2}$ and $95 \%$ air at $37^{\circ} \mathrm{C}$. LMH cells were grown in Waymouth's MB 752/1 medium (Invitrogen) containing 10\% FBS, 100 units $/ \mathrm{ml}$ penicillin and $100 \mu \mathrm{g} / \mathrm{ml}$ streptomycin at $37^{\circ} \mathrm{C}$ in an atmosphere of $95 \%$ air and $5 \% \mathrm{CO}_{2}$.

\section{Effect of leptin in COS-7 cells transiently transfected with chLEPR}

Transient transfection was performed in 24-well plates. COS-7 cells $\left(0 \cdot 8 \times 10^{5}\right.$ cells/well $)$ were transfected with $\mathrm{pCI}$-chLEPR or pCIneo vector (Promega), $\mathrm{pAH} 32$ and $\mathrm{pRL}-\mathrm{Tk}$ at a ratio of 1:4:0·1 using TransFectin Lipid Reagent (Bio-Rad) according to the manufacturer's protocol. Four hours after treatment, growth medium was replaced with serum-free medium and recombinant murine leptin $(125 \mathrm{ng} / \mathrm{ml}$; Sigma) was applied for $24 \mathrm{~h}$, and a dual luciferase assay was then performed.

\section{Creation of stable cell line}

Transfection was performed in 24-well plates. The cells $(1 \cdot 0 \times$ $10^{5}$ ) were transfected with $0 \cdot 5 \mu \mathrm{g}$ pCI-chLEPR using TransFectin Lipid Reagent according to the manufacturer's protocol. Twenty-four hours after transfection, stable clones were selected using CHO-K1 growth medium supplemented with $500 \mu \mathrm{g} / \mathrm{ml}$ G418 (Invitrogen). RT-PCR could isolate clones expressing chLEPR mRNA from among the clones selected by G418. Briefly, total RNA was extracted from the G418-resistant cells using Sepazol Super (Nacalai Tesque, Kyoto, Japan) according to the manufacturer's instructions and treated with RQ1 RNasefree DNase (Promega) at $37^{\circ} \mathrm{C}$ for $15 \mathrm{~min}$. One microgram of DNA-free $\mathrm{RNA}$ was reverse transcribed with oligo- $\mathrm{dT}_{17}$ primer and ReverTra Ace (Toyobo, Osaka, Japan). The cDNA fragment of chLEPR was amplified using GoTaq DNA polymerase (Promega) with a pair of primers specific to chLEPR (5'-TGGAGAACTGTCACTGAAGA- $3^{\prime}$ as sense primer and $5^{\prime}$-CCTCCTTGAACGTGGGTGAA- ${ }^{\prime}$ as antisense primer) and the reverse-transcribed cDNA or DNA-free RNA as the control using 30 cycles of PCR consisting of denaturation for $30 \mathrm{~s}$ at $95^{\circ} \mathrm{C}$, annealing for $30 \mathrm{~s}$ at $60{ }^{\circ} \mathrm{C}$ and extension for $30 \mathrm{~s}$ at $72^{\circ} \mathrm{C}$. The PCR reactants were separated by $1 \%$ agarose gel electrophoresis to determine chLEPR mRNA expression and we chose the clone, $\mathrm{CHO}$-chLEPR, that expressed the greatest amount of chLEPR mRNA.

\section{Leptin-induced activation of luciferase activity in CHO-chLEPR cells}

The CHO-chLEPR cells $\left(1 \cdot 0 \times 10^{5}\right.$ cells/well $)$ were seeded in 24-well plates and transfected with pAH32 and pRL-Tk at a ratio of 49:1 using TransFectin Lipid Reagent (Biorad) according to the manufacturer's protocol. Four hours after transfection, growth medium was changed to serum-free medium and the cells were stimulated with various concentrations of mouse leptin for $24 \mathrm{~h}$; this was followed by the dual luciferase assay (see below).

\section{Dual luciferase assay}

The cells were lysed with $100 \mu \mathrm{l}$ PicaGene Dual Cell Culture Lysis Reagent (Nippon Gene, Toyama, Japan), and luciferase activity was measured using a PicaGene Dual SeaPansy Luminescence Kit (Nippon Gene) according to the manufacturer's instructions. Firefly luciferase activity was normalised to Renilla luciferase activity.

\section{Determination of phosphorylated STAT3 by Western blot analysis}

COS-7 cells $\left(3 \cdot 0 \times 10^{5}\right)$ maintained in DMEM with $10 \%$ LiforCell FBS (Lifeblood Medical) were seeded in $35 \mathrm{~mm}$ dishes and transfected with $2 \mu \mathrm{g}$ pCI-chLEPR or pCIneo vector using TransFectin Lipid Reagent. Twenty-four hours after transfection, the cells were treated with recombinant murine leptin $(125 \mathrm{ng} / \mathrm{ml}$; Sigma) for $1 \mathrm{~h}$. After leptin treatment, the cells were lysed with $50 \mu \mathrm{l}$ mild lysis solution (CytoSignal, Irvine, CA, USA) containing protease inhibitors (Complete; Roche Applied Science) and Phosphatase Inhibitor Cocktail (Nacalai Tesque). The protein concentration of the cell lysates was measured using BCA Protein Assay Reagent (Pierce Biotechnology, Rockford, IL, USA). Thirty micrograms of whole-cell lysate were separated by $8 \%$ SDS-PAGE followed by transfer onto Hybond-P membrane (Amersham Biosciences). After transfer, the blot was blocked 
in Blocking One-P Solution (Nacalai Tesque) for $20 \mathrm{~min}$, followed by incubation with anti-STAT3 monoclonal antibody (BD Biosciences, Tokyo, Japan) or anti-STAT3 (pY705) monoclonal antibody (BD Biosciences) for $1 \mathrm{~h}$ at room temperature. Then, the membrane was washed twice with PBS containing $0 \cdot 1 \%$ Tween 20 (PBST) for $10 \mathrm{~min}$, treated with anti-mouse IgG secondary antibody conjugated with horseradish peroxidase (1:2000 dilution; New England BioLabs Japan, Tokyo, Japan) for $1 \mathrm{~h}$ and washed twice with PBST for $10 \mathrm{~min}$. After washing, the membrane was immersed in SuperSignal West Dura Extended Duration Substrate (Pierce Biotechnology) and the signals were detected using Light Capture (Atto Corporation Ltd, Tokyo, Japan).

\section{Effect of JAK2 inhibitor AG490 on leptin-induced luciferase activity in CHO-K1 cells stably expressing chLEPR}

Transfection was demonstrated using the procedure described above. Four hours after transfection, the medium was replaced with serum-free medium and incubation was performed for $16 \mathrm{~h}$. Then the cells were treated with leptin for $3 \mathrm{~h}$ after pretreatment with or without $25 \mu \mathrm{M}$ AG490 (Sigma) for $1 \mathrm{~h}$, followed by the dual luciferase assay described above.

Effect of $\operatorname{siRN} A$ on $\mathrm{chLEPR} m R N A$ and protein expression in COS-7 cells transfected with chLEPR expression vector

An siRNA duplex was designed on the basis of the published sequence of chLEPR (Ohkubo et al. 2000). The siRNA duplex for chLEPR (chLEPR siRNA), which corresponds to bases 112-130 of the open reading frame of chLEPR mRNA: $5^{\prime}$-CUACUGCUGAAUGAGACAU-dTdT- $3^{\prime}$, and the negative siRNA control, which is a scrambled sequence of chLEPR siRNA: 5'-AACACUCUAGUCUGGGAUAdTdT-3', were both synthesised by TaKaRa Bio (Tokyo, Japan). COS-7 cells maintained in DMEM containing $10 \%$ FBS $\left(3 \times 10^{5}\right.$ cells) were seeded in $35 \mathrm{~mm}$ culture dishes and transfected with $2 \mu \mathrm{g}$ each of chLEPR or control siRNA and pCI-chLEPR using X-treme GENE siRNA transfection reagent (Roche Applied Science) according to the manufacturer's instructions. Twenty-four hours after transfection, the cells were harvested to be used in the following experiments. To study chLEPR mRNA expression, total RNA was extracted from the cells using Sepazol Super according to the manufacturer's instructions. One microgram of total RNA was reverse transcribed with oligo- $\mathrm{dT}_{17}$ primer and ReverTra Ace. The cDNA fragment of chLEPR was amplified using GoTaq DNA polymerase (Promega) with the same pair of primers and PCR procedures as described above. Glyceraldehyde-3phosphate dehydrogenase (GAPDH) cDNA was amplified using a pair of primers (5'-ACTGGCGTCTTCACCACCATGGAG- $3^{\prime}$ as sense primer and $5^{\prime}$-ACACGGAAGGCCATGCCAGTGAGC- $3^{\prime}$ as antisense primer) that served as the internal control under the same conditions as those described above except that the number of cycles was reduced to 25 . The PCR product was separated by electrophoresis on a
$1 \%$ agarose gel and this was followed by staining with ethidium bromide to visualise the amplified bands. For detection of chLEPR protein, the cells were lysed with $100 \mu \mathrm{l}$ mild lysis solution (CytoSignal) and of which protein concentration was measured using BCA Protein Assay Reagent (Pierce Biotechnology). Then, $7 \mu \mathrm{g}$ lysates were separated by $6 \%$ SDSPAGE followed by western blot analysis using the method described previously (Ohkubo et al. 2007).

Effect of chLEPR siRNA on luciferase activity in CHO-K1 cells stably expressing chLEPR

CHO-chLEPR cells seeded in 24-well plates were transfected with the siRNAs described above, pAH32 and pRL-Tk, at a ratio of 50:49:1, using X-treme GENE siRNA transfection reagent (Roche Applied Science) according to the manufacturer's instructions. Four hours after transfection, the medium was replaced with Ham's F-12 medium containing 10\% LiforCell FBS replacement (Lifeblood Medical), left for $16 \mathrm{~h}$ and then stimulated with recombinant mouse leptin $(12.5 \mathrm{ng} / \mathrm{ml})$ for $3 \mathrm{~h}$. After this treatment, the dual luciferase assay was performed.

Leptin-induced signal transduction in the chicken hepatoma cell line, $\mathrm{LMH}$

LMH cells $\left(8 \cdot 0 \times 10^{5}\right)$ maintained in Waymouth's MB 752/1 medium with 10\% LiforCell FBS (Lifeblood Medical) were seeded in $35 \mathrm{~mm}$ dishes and transfected with $2 \mu \mathrm{g}$ pCIchLEPR or pCIneo vector using TransFectin Lipid Reagent. Twenty-four hours after transfection, the cells were treated with recombinant murine leptin (125 $\mathrm{ng} / \mathrm{ml}$ Sigma) for $1 \mathrm{~h}$. After leptin treatment, the cells were lysed with $50 \mu \mathrm{l}$ mild lysis solution (CytoSignal) containing protease inhibitors (Complete; Roche Applied Science) and Phosphatase Inhibitor Cocktail (Nacalai Tesque). The protein concentration of the cell lysates was measured using BCA Protein Assay Reagent (Pierce Biotechnology). Thirty micrograms of whole-cell lysate were separated by $8 \%$ SDS-PAGE followed by transfer onto Hybond-P membrane (Amersham Biosciences). Then, western blot analysis for phosphorylated STAT3 was demonstrated as described above. For determination of chLEPR protein, $7 \mu \mathrm{g}$ whole cell lysates were separated by $6 \%$ SDS-PAGE followed by western blot analysis using the method described previously (Ohkubo et al. 2007).

To determine leptin-induced activation of luciferase activity, LMH cells $\left(1.5 \times 10^{5}\right.$ cells/well) seeded in 24-well plates were transfected with $\mathrm{pCI}-\mathrm{chLEPR}$ or $\mathrm{pCIneo}$ vector, pAH32 and pRL-Tk at a ratio of 1:4:0.1 using TransFectin Lipid Reagent (Bio-Rad) according to the manufacturer's instructions. Four hours after transfection, the medium was replaced with Waymouth's medium containing 10\% LifoCell FBS replacement (Lifeblood Medical) and incubated for $16 \mathrm{~h}$. After treatment, the cells were stimulated with recombinant murine leptin at a concentration of $12.5 \mathrm{ng} / \mathrm{ml}$ for $3 \mathrm{~h}$ and the dual luciferase assay was then performed. 


\section{Statistical analysis}

The data in Figs 1, 3, 5 and 6 were analysed by Tukey's test for multiple comparison followed by ANOVA.

\section{Results}

Functional analysis of leptin in COS-7 cells transiently expressing chLEPR

The basal luciferase activity was higher in COS-7 cells co-transfected with pCI-chLEPR and pAH32 vectors compared with control cells transfected with empty pCIneo vector and $\mathrm{pAH} 32$. Leptin treatment increased luciferase activity in chLEPR-expressing COS-7 cells, whereas luciferase activity in the control cells was similar with and without leptin treatment (Fig. 1a). Furthermore, in COS-7 cells transiently expressing chLEPR, STAT3 was phosphorylated

(a)

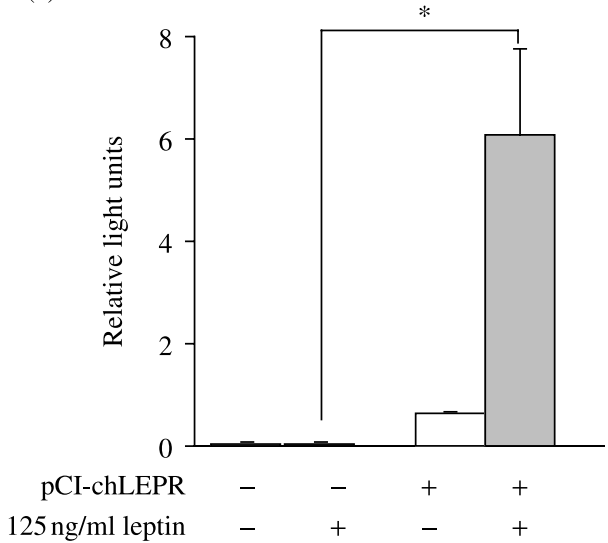

(b)

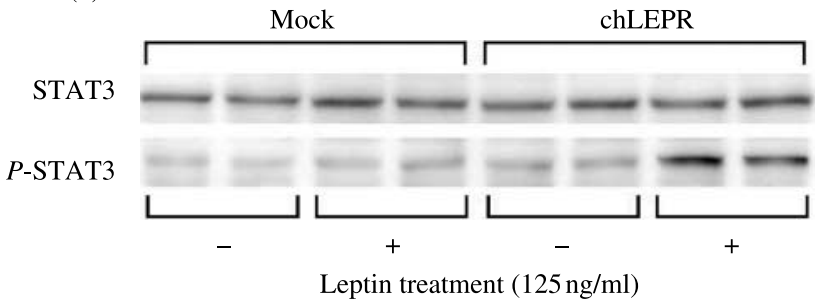

Figure 1 Effect of leptin on COS-7 cells transiently transfected with chLEPR. (a) Determination of luciferase activity in response to leptin stimulation. Four hours after co-transfection with pAH32 and either $\mathrm{pCl}$-chLEPR or $\mathrm{pCl}$ neo vector, the cells were placed in serum-free DMEM and treated with $125 \mathrm{ng} / \mathrm{ml}$ mouse leptin for $24 \mathrm{~h}$ and followed by dual luciferase assay. Results represent the average of four measurements \pm s.E.M. Asterisk indicates a difference $(P<0 \cdot 01)$ between the luciferase activity of control transfection and that of pCl-chLEPR transfection with $125 \mathrm{ng}$ mouse leptin. (b) Effect of leptin on phosphorylation of STAT3. COS-7 cells transiently transfected with chLEPR was stimulated with leptin $(12.5 \mathrm{ng} / \mathrm{ml})$ for 0 and $1 \mathrm{~h}$ before lysis. The cell lysates were subjected to western blot analysis using anti-STAT3 (STAT3) or anti-STAT3 (pY705) (P-STAT3) antibody. Result shows two independent experiments. by leptin treatment but the STAT3 protein level was not affected (Fig. 1b).

\section{Leptin-induced luciferase activity in CHO-chLEPR cells}

We established a cell line stably expressing chLEPR using CHO-K1 cells (CHO-chLEPR), and the line was transfected with pAH32 to measure leptin-dependent activation of the reporter gene. Concentrations of murine leptin up to $1.25 \mathrm{ng} / \mathrm{ml}$ did not result in obvious induction of luciferase; concentrations from 1.25 to $125 \mathrm{ng} / \mathrm{ml}$ leptin dose dependently increased luciferase activity in CHO-chLEPR cells transfected with pAH32 (Fig. 2). Luciferase activity was not detected in leptin-treated CHO-K1 cells transfected with pAH32 (data not shown).

\section{Effect of leptin on JAK-STATactivation in CHO-chLEPR cells}

To confirm that the JAK-STAT pathway is involved in leptininduced luciferase activity in CHO-chLEPR cells, we measured leptin-induced luciferase activity using a JAK2 inhibitor, AG490. This inhibitor had a partial inhibitory effect on the luciferase activity stimulated by leptin (Fig. 3).

Effect of siRNA on chLEPR $m R N A$ and protein expression in COS-7 cells transfected with chLEPR expression vector

Transient chLEPR mRNA expression was reduced when COS-7 cells were co-transfected for $24 \mathrm{~h}$ with pCI-chLEPR and chLEPR siRNA than when cells were transfected with pCI-chLEPR and control siRNA, whereas GAPDH expression was not altered in the same cells transfected with

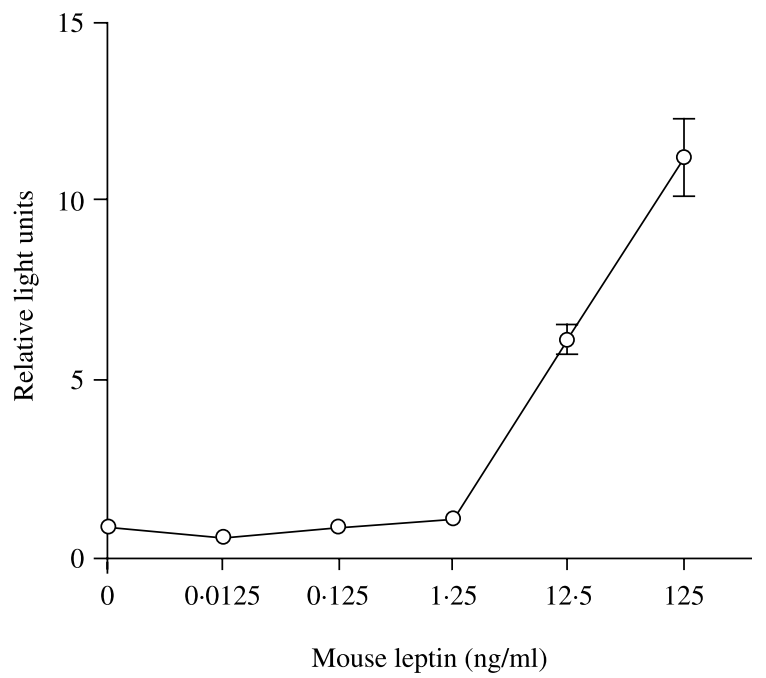

Figure 2 Dose-dependent stimulation of luciferase expression in response to leptin treatment in $\mathrm{CHO}$-chLEPR cells. The cells were treated with various amounts of leptin for $24 \mathrm{~h}$ and followed by dual luciferase assay. Results represent the average of four measurements \pm S.E.M. 


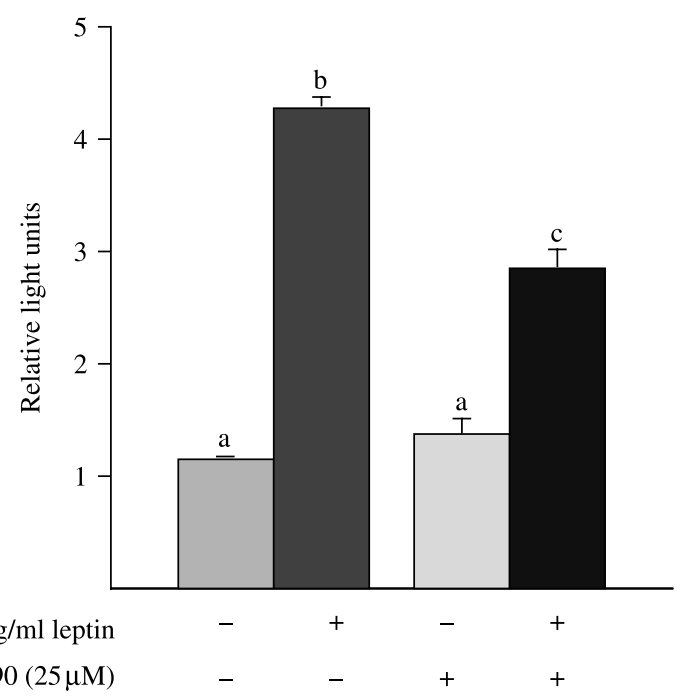

Figure 3 Effect of JAK2 inhibitor on leptin-induced luciferase activity in CHO-chLEPR cells. Transfected cells with pAH32 were pretreated with $25 \mu \mathrm{M}$ AG490, thereafter the cells were stimulated with leptin $(12.5 \mathrm{ng} / \mathrm{ml})$ for $3 \mathrm{~h}$. Then, luciferase activity was measured by dual luciferase assay. Results represent the average of four measurements \pm S.E.M. The bars with different letters differ significantly $(P<0 \cdot 01)$.

pCI-chLEPR vector and either chLEPR siRNA or control siRNA (Fig. 4a). Regarding protein expression, western blot analysis showed that $24 \mathrm{~h}$ of chLEPR siRNA treatment decreased the chLEPR protein level in cells transfected with chLEPR expression vector (Fig. 4b). The same effect was also observed in cells in which chLEPR treatment was extended to $48 \mathrm{~h}$ (data not shown).

\section{Effect of siRNA on leptin-dependent promoter activity in CHO-chLEPR cells}

Basal promoter activity without leptin treatment was decreased in CHO-chLEPR cells transfected with chLEPR siRNA compared with the cells treated with control siRNA. Furthermore, CHO-chLEPR cells treated with chLEPR siRNA showed lower STAT-dependent luciferase activity than the cells treated with control siRNA when the cells were treated with leptin for $3 \mathrm{~h}$ (Fig. 5).

\section{Functional assay of leptin in LMH cells}

Western blot analysis showed transfection of pCI-chLEPR increased chLEPR protein level in the LMH cells, whereas the protein expression was not detected in the mock-transfected LMH. In addition, STAT3 was phosphorylated by leptin treatment but the STAT3 protein level was not affected in the LMH cells transfected with pCI-chLEPR vector (Fig. 6a). In luciferase assay, the basal luciferase activity was higher in the LMH cells co-transfected with pCI-chLEPR and pAH32 vectors compared with the control cells transfected with empty

\section{(a) \\ GAPDH}
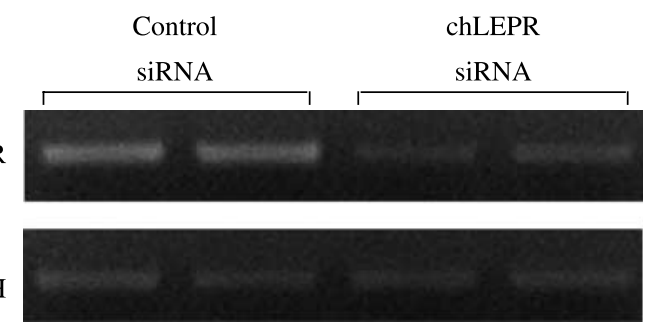

(b)

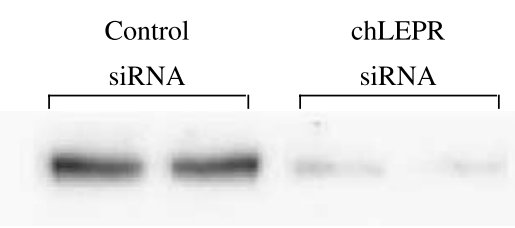

Figure 4 siRNA-mediated downregulation of chLEPR in COS-7 cells transfected with pCI-LEPR. (a) RT-PCR analysis for chLEPR expression from COS-7 cells co-transfected with pCI-LEPR and chLEPR siRNA or control siRNA. Twenty-four hours after transfection, $1 \mu \mathrm{g}$ total RNA prepared from the transfected cells was subjected to RT-PCR. The PCR was demonstrated using specific primers to chLEPR and GAPDH as the control. The PCR product was separated by $1 \%$ agarose gel electrophoresis and stained with ethidium bromide to visualise the amplified band. Data represent a result from two independent experiments. (b) Western blot prepared from COS-7 cells co-transfected with pCI-LEPR and chLEPR siRNA or control siRNA. Twenty-four hours after transfection, $7 \mu \mathrm{g}$ cell lysates were separated in $6 \%$ SDS-PAGE followed by western blot analysis for chLEPR using a method described previously (Ohkubo et al. 2007). Data represent a result from two independent experiments.

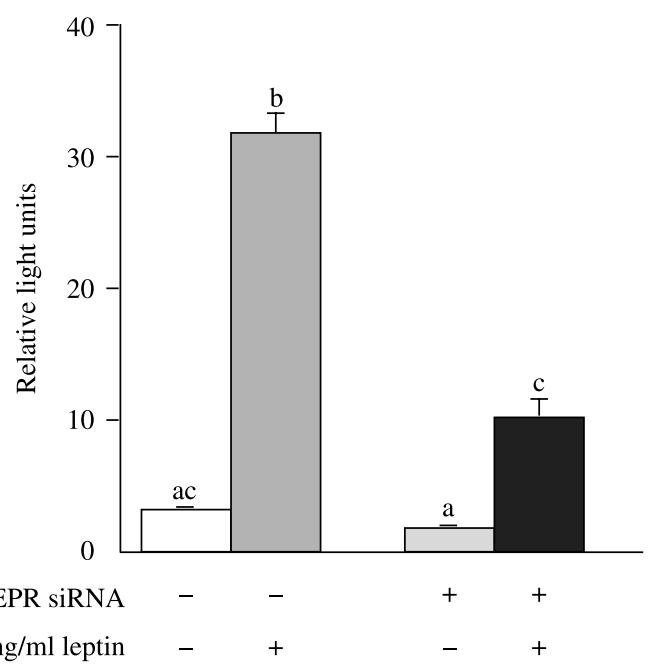

Figure 5 siRNA-mediated downregulation of luciferase expression in CHO-chLEPR cells. CHO-chLEPR cells were co-transfected with pAH32, pRL-Tk and chLEPR siRNA or control siRNA. Four hours after transfection, the cells were placed in F-12 Ham containing 1\% FBS and incubated another $24 \mathrm{~h}$. Then, the cells were treated with $125 \mathrm{ng} / \mathrm{ml}$ mouse leptin for $3 \mathrm{~h}$ and followed by dual luciferase assay. Results represent the average of four measurements \pm S.E.M. The bars with different letters differ significantly $(P<0 \cdot 01)$. 

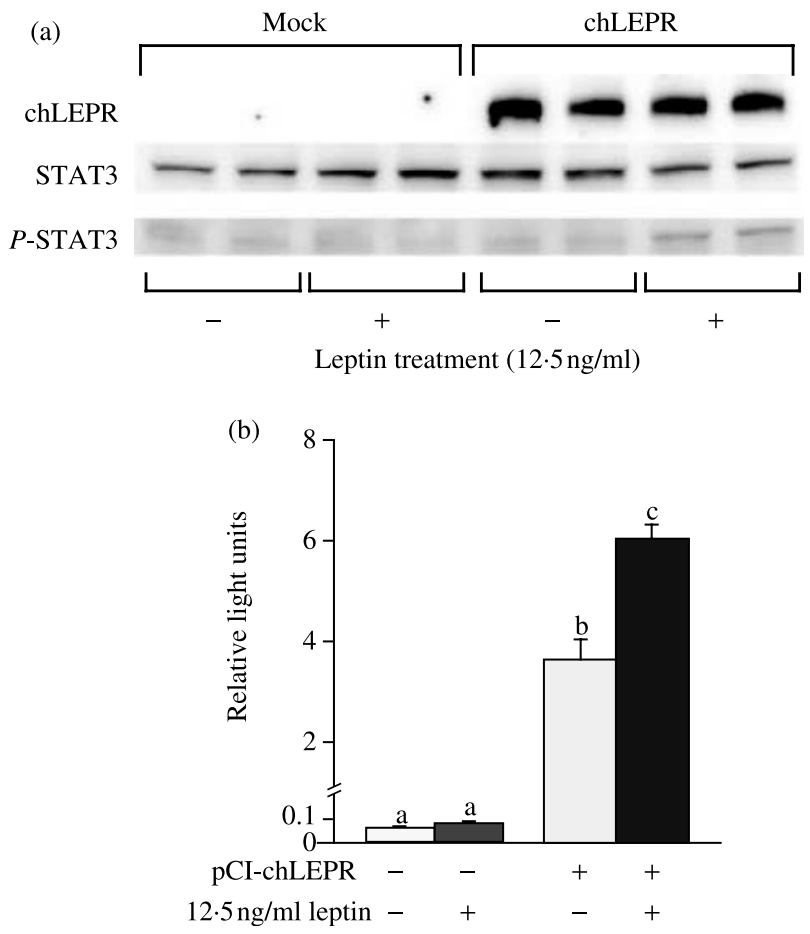

Figure 6 Leptin-induced signal transduction in LMH cells. (a) Effect of leptin on phosphorylation of STAT3. LMH cells transiently transfected with chLEPR was stimulated with leptin $(12.5 \mathrm{ng} / \mathrm{ml})$ for 0 and $1 \mathrm{~h}$ before lysis. The cell lysates were subjected to western blot analysis using anti-chLEPR (chLEPR), anti-STAT3 (STAT3) or anti-STAT3 (pY705) (P-STAT3) antibody. Result shows two independent experiments. (b) Determination of luciferase activity in response to leptin treatment in $\mathrm{LMH}$ cells transiently express chLEPR. Four hours after co-transfection with pAH32, pRL-Tk and either $\mathrm{pCl}$-chLEPR or $\mathrm{pClneo}$ vector, the cells were placed in Waymouth's medium containing $10 \%$ LiforCell and left for $16 \mathrm{~h}$, and then treated with $12.5 \mathrm{ng} / \mathrm{ml}$ mouse leptin for $3 \mathrm{~h}$ and determined luciferase activity by dual luciferase assay. Results represent the average of four measurements \pm s.E.M. The bars with different letters differ significantly $(P<0 \cdot 01)$.

pCIneo vector and pAH32. Short-term leptin treatment increased luciferase activity in chLEPR-expressing LMH cells, whereas luciferase activity in mock-transfected control cells did not show any significant induction of luciferase activity (Fig. 6b).

\section{Discussion}

Although evidence for a gene encoding chicken leptin is controversial (Friedman-Einat et al. 1999, Pitel et al. 2000, Dunn et al. 2001), exogenous leptin has physiological effects in the chicken. For instance, administration of recombinant human leptin reduced food intake in several breeds of chicken (Denbow et al. 2000, Cassy et al. 2004, Kuo et al. 2005), and injection of recombinant chicken leptin, which is almost identical to murine leptin, caused advanced puberty in a layer strain of chickens (Paczoska-Eliasiewicz et al. 2006).
Furthermore, we recently showed that the long isoform of LEPR is translated in chicken tissues (Ohkubo et al. 2007). These observations strongly indicate that receptors for leptin located in chicken tissues are functional. The JAK-STAT is known to be a major signalling pathway of leptin, since STAT3 is activated in a dose-dependent fashion in vivo (Vaisse et al. 1996), and a functional bioassay of leptin based on the STAT-dependent activation of a reporter gene has been developed in several mammals (Rosenblum et al. 1998, Ju et al. 2001). To assess the functionality of the LEPR in the chicken, we studied leptin-dependent activation of a reporter gene via chLEPR using a similar system developed in mammalian cells. Recombinant murine leptin induced luciferase activity in COS-7 cells transiently transfected with chLEPR expression vector, whereas such activation did not occur in COS-7 cells without chLEPR expression (Fig. 1a). In addition, leptin induced phosphorylation of STAT3 in the COS-7 expressing chLEPR (Fig. 1b). Furthermore, we developed CHO-K1 cells stably expressing chLEPR, CHO-chLEPR, in which we found that leptin dose dependently increased luciferase activity (Fig. 2). pAH32 is a reporter vector transactivated by leptin via the JAK-STAT signalling cascade (Rosenblum et al. 1996, 1998). In the present study, we showed that STAT3 was phosphorylated in COS-7 cells transiently expressing chLEPR and that the JAK2 inhibitor, AG490, partially inhibited leptin-induced activation of luciferase activity (Fig. 3). It has also been shown that AG490 inhibits leucine incorporation by leptin and phosphorylation of STAT3 (Shin et al. 2005). Phosphorylation of STAT3 by leptin was observed in mammalian LEPRb-transfected COS-7 cells (Bahrenberg et al. 2002) and CHO cells (Yamashita et al. 1998). In addition, a pair of hydrophobic amino acids (Leu896 and Phe897) in the cytoplasmic region of murine LEPRb was critical in signalling, and these amino acids were conserved in LEPR $b$ in mammals and birds (Bahrenberg et al. 2002). Therefore, it is likely that endogenous STATs in mammalian cells are transactivated by leptin through chLEPR. However, in the present study, low doses of murine leptin led to less induction of luciferase activity (Fig. 2). This phenomenon may be explained by the lower binding activity of murine leptin to chLEPR. It has been reported that, compared with human leptin, rat leptin stimulates a higher fold induction of luciferase activity in $\mathrm{CHO}$ cells stably transfected with rat LEPRb (Ju et al. 2001). Therefore, we tested the transactivation of STAT by chicken serum using CHO-chLEPR with a reporter vector; however, we did not find any induction of luciferase activity by chicken serum (data not shown). This might have been because the level of leptin in the chicken is too low for the signal to have been detected in the present assay, as was suggested by Dridi et al. (2000).

The use of 21-nucleotide siRNA duplexes to silence the expression of specific genes in mammalian somatic cells, without the activation of the non-specific interferon response, is a powerful experimental tool for studying gene function. We therefore tested the effect of siRNA for chLEPR on the 
leptin-dependent activation of STAT-inducible luciferase. As shown in Fig. 4, chLEPR siRNA effectively blocked transient chLEPR mRNA and protein expression in COS-7 cells transfected with pCI-chLEPR, which indicates that chLEPR siRNA clearly suppresses chLEPR expression in vitro. Regarding the effect of chLEPR siRNA on leptin-dependent signal transduction, leptin-dependent luciferase activity was reduced when CHO-chLEPR cells were transfected with chLEPR siRNA (Fig. 5). These results are consistent with the finding that siRNA for peroxisome proliferator-activated receptor- $\gamma$ prevented the subsequent signal transduction cascade (Polikandriotis et al. 2005), which also suggests that the luciferase activity induced by leptin was the result of a specific effect acting via the chLEPR introduced into the $\mathrm{CHO}-\mathrm{K} 1$ cells.

It is well known that cytokine receptors, including the LEPR, can mediate a signal via the JAK-STAT cascade in vivo and in vitro in mammals. Although there is no direct evidence that leptin activates the JAK-STAT pathway to initiate its actions in the chicken, a few studies on the in vivo activation of JAK-STAT by cytokines are documented in birds. Platelet-derived growth factor and granulocytemacrophage colony-stimulating factor (GM-CSF) phosphorylate STAT1 and STAT3 in chicken lens cells (Potts et al. 1998). GM-CSF activates JAK2 and STAT3 to induce angiogenesis in the chick chorioallantoic membrane (Valdembri et al. 2002). Therefore, we investigated leptininduced luciferase activation in LMH cells, a chickenderived hepatoma cell line that is known to express LEPR protein (Ohkubo et al. 2007) and in which leptin downregulates LEPR mRNA expression (Cassy et al. 2003). We showed that leptin treatment induced phosphorylation of STAT3 and luciferase activity in the LMH cells overexpressing chLEPR (Fig. 6). This result indicates that activated chicken STAT3 by leptin initiated following signal transduction as was shown in mammalian cells expressing chLEPR (Figs 1 and 3). However, we did not observe any significant induction of luciferase activity by leptin in the control LMH cells (Fig. 6b). This may be because LEPR expression in the LMH cells was extremely low to activate JAK-STAT pathway in the present experimental condition. This view is supported by a result that knockdown of chLEPR by its siRNA prevented leptin-induced activation of luciferase activity in CHO-chLEPR cells (Fig. 5). Nevertheless, we first demonstrated that leptin can activate JAK-STAT signalling cascade in chicken-derived cells and which may indicate that LEPR expressed in chicken tissues may bind with endogenous ligand to induce physiological processes, and the reported actions of exogenous mammalian leptin in birds are initiated by the binding of leptin to LEPR located in chicken tissues.

In conclusion, we have established a cell line that stably expresses chLEPR and can activate the JAK-STAT signal transduction pathway. This result strongly indicates that chLEPR located in chicken tissues is a functional receptor that brings about physiological actions associated with leptin.

\section{Acknowledgements}

We thank Dr C I Rosenblum, Department of Obesity Research, Merck Research Laboratories, for providing pAH32 reporter vector. This study was supported in part by a Grant-in-Aid for Scientific Research for the Promotion of Sciences to T O and $\mathrm{T} B$. The authors declare that there is no conflict of interest that would prejudice the impartiality of this scientific work.

\section{References}

Amills M, Jimenez N, Villalba D, Tor M, Molina E, Cubilo D, Marcos C, Francesch A, Sanchez A \& Estany J 2003 Identification of three single nucleotide polymorphisms in the chicken insulin-like growth factor 1 and 2 genes and their associations with growth and feeding traits. Poultry Science $\mathbf{8 2}$ 1485-1493.

Ashwell CM, Czerwinski SM, Brocht DM \& McMurtry JP 1999 Hormonal regulation of leptin expression in broiler chickens. American Journal of Physiology 276 R226-R232.

Bahrenberg G, Behrmann I, Barthel A, Hekerman P, Heinrich PC, Joost HG \& Becker W 2002 Identification of the critical sequence elements in the cytoplasmic domain of leptin receptor isoforms required for Janus kinase/signal transducer and activator of transcription activation by receptor heterodimers. Molecular Endocrinology 16 859-872.

Baumann H, Morella KK, White DW, Dembski M, Bailon PS, Kim H, Lai CF \& Tartaglia LA 1996 The full-length leptin receptor has signaling capabilities of interleukin 6-type cytokine receptors. PNAS 93 8374-8378.

Campfield LA, Smith FJ, Guisez Y, Devos R \& Burn P 1995 Recombinant mouse $\mathrm{OB}$ protein: evidence for a peripheral signal linking adiposity and central neural networks. Science 269 546-549.

Cassy S, Derouet M, Crochet S, Dridi S \& Taouis M 2003 Leptin and insulin downregulate leptin receptor gene expression in chicken-derived leghorn male hepatoma cells. Poultry Science 82 1573-1579.

Cassy S, Derouet M, Crochet S, Dridi S \& Taouis M 2004 Peripheral leptin effect on food intake in young chickens is influenced by age and strain. Domestic Animal Endocrinology 27 51-61.

Denbow DM, Meade S, Robertson A, McMurtry JP, Richards M \& Ashwell C 2000 Leptin-induced decrease in food intake in chickens. Physiology and Behavior 69 359-362.

Dridi S, Williams J, Bruggeman V, Onagbesan M, Raver N, Decuypere E, Djiane J, Gertler A \& Taouis M 2000 A chicken leptin-specific radioimmunoassay. Domestic Animal Endocrinology 18 325-335.

Dunn IC, Girishvarma G, Talbot RT, Waddington D, Boswell T \& Sharp PJ 2001 Evidence for low homology between the chicken and mammalian leptin genes. In Avian Endocrinology, pp 327-336. Eds A Dawson \& CM Chaturvedi. New Delhi: Narosa Publishing House.

Friedman-Einat M, Boswell T, Horev G, Girishvarma G, Dunn IC, Talbot RT \& Sharp PJ 1999 The chicken leptin gene: has it been cloned? General and Comparative Endocrinology 115 354-363.

Friedman-Einat M, Camoin L, Faltin Z, Rosenblum CI, Kaliouta V, Eshdat Y \& Strosberg AD 2003 Serum leptin activity in obese and lean patients. Regulatory Peptides 111 77-82.

Ghilardi N, Ziegler S, Wiestner A, Stoffel R, Heim MH \& Skoda RC 1996 Defective STAT signaling by the leptin receptor in diabetic mice. PNAS $\mathbf{9 3}$ 6231-6235.

Halaas JL, Gajiwala KS, Maffei M, Cohen SL, Chait BT, Rabinowitz D, Lallone RL, Burley SK \& Friedman JM 1995 Weight-reducing effects of the plasma protein encoded by the obese gene. Science 269 543-546.

Horev G, Einat P, Aharoni T, Eshdat Y \& Friedman-Einat M 2000 Molecular cloning and properties of the chicken leptin-receptor (CLEPR) gene. Molecular and Cellular Endocrinology 162 95-106.

Ju SK, Park JH, Na SY, You KH, Kim KL \& Lee MK 2001 Determination of rat leptin activity in vitro using a novel luciferase reporter assay. Molecules and Cells 12 131-136. 
Kuo AY, Cline MA, Werner E, Siegel PB \& Denbow DM 2005 Leptin effects on food and water intake in lines of chickens selected for high or low body weight. Physiology and Behavior 84 459-464.

Lee G-H, Proenca R, Montez JM, Carroll KM, Darvishzadeh JG, Lee JI \& Friedman JM 1996 Abnormal splicing of the leptin receptor in diabetic mice. Nature $379632-635$.

Lohmus M, Olin M, Sundstrom LF, Troedsson MH, Molitor TW \& El Halawani M 2004 Leptin increases T-cell immune response in birds. General and Comparative Endocrinology 139 245-250.

McMurtry JP, Ashwell CM, Brocht DM \& Caperna TJ 2004 Plasma clearance and tissue distribution of radiolabeled leptin in the chicken. Comparative Biochemistry and Physiology. Part A, Molecular \& Integrative Physiology 138 27-32.

Ohkubo T, Tanaka M \& Nakashima K 2000 Structure and tissue distribution of chicken leptin receptor (cOb-R) mRNA. Biochimica et Biophysica Acta 1491 303-308.

Ohkubo T, Nishio M, Tsurudome M, Ito M \& Ito Y 2007 Existence of leptin receptor protein in chicken tissues: isolation of a monoclonal antibody against chicken leptin receptor. General and Comparative Endocrinology 151 269-273.

Paczoska-Eliasiewicz HE, Gertler A, Proszkowiec M, Proudman J, Hrabia A, Sechman A, Mika M, Jacek T, Cassy S, Raver N et al. 2003 Attenuation by leptin of the effects of fasting on ovarian function in hens (Gallus domesticus). Reproduction 126 739-751.

Paczoska-Eliasiewicz HE, Proszkowiec-Weglarz M, Proudman J, Jacek T, Mika M, Sechman A, Rzasa J \& Gertler A 2006 Exogenous leptin advances puberty in domestic hen. Domestic Animal Endocrinology 31 211-226.

Pelleymounter MA, Cullen MJ, Baker MB, Hecht R, Winters D, Boone T \& Collins F 1995 Effects of the obese gene product on body weight regulation in ob/ob mice. Science $269540-543$.

Pitel F, Monbrum C, Gellin J \& Vignal A 2000 The chicken LEP (OB) gene has not been mapped. Animal Genetics 31281.

Polikandriotis JA, Mazzella LJ, Rupnow HL \& Hart CM 2005 Peroxisome proliferator-activated receptor gamma ligands stimulate endothelial nitric oxide production through distinct peroxisome proliferator-activated receptor gamma-dependent mechanisms. Arteriosclerosis, Thrombosis, and Vascular Biology 25 1810-1816.

Potts JD, Kornacker S \& Beebe DC 1998 Activation of the JAK-STATsignaling pathway in embryonic lens cells. Developmental Biology 204 277-292.
Richards MP \& Poch SM 2003 Molecular cloning and expression of the turkey leptin receptor gene. Comparative Biochemistry and Physiology. Part B, Biochemistry and Molecular Biology 136 833-847.

Rosenblum CI, Tota M, Cully D, Smith T, Collum R, Qureshi S, Hess JF, Phillips MS, Hey PJ, Vongs A et al. 1996 Functional STAT 1 and 3 signaling by the leptin receptor (OB-R); reduced expression of the rat fatty leptin receptor in transfected cells. Endocrinology 137 5178-5181.

Rosenblum CI, Vongs A, Tota MR, Varnerin JP, Frazier E, Cully DF, Morsy MA \& Van der Ploeg LH 1998 A rapid, quantitative functional assay for measuring leptin. Molecular and Cellular Endocrinology 143 117-123.

Schindler C \& Darnell JE, Jr 1995 Transcriptional responses to polypeptide ligands: the JAK-STAT pathway. Annual Review of Biochemistry 64 621-651.

Shin H-J, Oh J, Kang SM, Lee JH, Shin M-J, Hwang K-C, Jang Y \& Chung JH 2005 Leptin induces hypertrophy via p38 mitogen-activated protein kinase in rat vascular smooth muscle cells. Biochemical and Biophysical Research Communications 329 18-24.

Taouis M, Chen JW, Daviaud C, Dupont J, Derouet M \& Simon J 1998 Cloning the chicken leptin gene. Gene 208 239-242.

Tartaglia LA, Dembski M, Weng X, Deng N, Culpepper J, Devos R, Richards GJ, Campfield LA, Clark FT, Deeds J et al. 1995 Identification and expression cloning of a leptin receptor, OB-R. Cell 83 1263-1271.

Vaisse C, Halaas JL, Horvath CM, Darnell JE, Jr, Stoffel M \& Friedman JM 1996 Leptin activation of Stat 3 in the hypothalamus of wild-type and $o b / o b$ mice but not $d b / d b$ mice. Nature Genetics 14 95-97.

Valdembri D, Serini G, Vacca A, Ribatti D \& Bussolino F 2002 In vivo activation of JAK2/STAT-3 pathway during angiogenesis induced by GM-CSF. FASEB Journal 16 225-227.

Yamashita T, Murakami T, Otani S, Kuwajima M \& Shima K 1998 Leptin receptor signal transduction: OBRa and OBRb of $f a$ type. Biochemical and Biophysical Research Communications 246 752-759.

\section{Received in final form 25 February 2008 \\ Accepted 5 March 2008 \\ Made available online as an Accepted Preprint 5 March 2008}

